\title{
Mapping a Cultural Studies of Law
}

\author{
Naomi Mezey \\ Georgetown University Law Center, mezeyn@law.georgetown.edu
}

This paper can be downloaded free of charge from:

https://scholarship.law.georgetown.edu/facpub/1525

http://ssrn.com/abstract=2686760

Naomi Mezey, Mapping a Cultural Studies of Law, in The Handbook of Law and Society 39-55 (Austin Sarat \& Patricia Ewick eds., Chichester, U.K.: Wiley-Blackwell 2015).

This open-access article is brought to you by the Georgetown Law Library. Posted with permission of the author. Follow this and additional works at: https://scholarship.law.georgetown.edu/facpub

Part of the Jurisprudence Commons, and the Law and Society Commons 


\title{
Mapping a Cultural Studies of Law
}

\author{
Naomi Mezey
}

\section{Introduction to a Cultural Studies of Law}

In this chapter I briefly map the terrain of a set of scholarly approaches that could be called a cultural analysis of law. A cultural analysis or a cultural studies of law generally starts with the dual premise that law is a set of meaning-making practices that exists within and is the product of a particular culture and that culture is a set of meaning-making practices that exists within and is the product of a particular set of laws (Geertz 1983; Coombe 1998; Sarat and Kearns 1998; Mezey 2001). In what follows I unpack and elaborate this foundational idea.

At a minimum, a cultural analysis of law involves a commitment to subjecting law to a deeply critical inquiry that does not adopt the law's own internal claims to meaning, truth, or legitimacy (Kahn 1999: 2). Neither does it assume that critiques are unencumbered or objective, as all scholars are themselves embedded in both law and culture. Most of this scholarship, however, either strives to create a critical distance from law's self-validating quality or it investigates the ways in which legal discourse is self-validating. What I take as foundational to a cultural study of law is that the relationship between law and culture is not merely constitutive, but "dynamic, interactive, and dialectical - law is both a producer of culture and an object of culture. Put generally, law shapes individual and group identity, social practices as well as the meaning of cultural symbols, but all of these things (culture in its myriad manifestations) also shape law by changing what is socially desirable, politically feasible, legally legitimate" (Mezey 2001: 46).

Methodologically, a cultural analysis of law borrows liberally from cultural and literary theory, anthropology, history, sociology, and philosophy and takes as its object of study law a set of cultural practices. Many approaches are possible from 
this diverse set of humanistic lenses, just as many possible avenues of inquiry flow from the basic assumption that law and culture are mutually constitutive. In mapping them, I repurpose James Clifford and Paul Gilroy's distinction between cultural roots and routes (Clifford, 1997; Gilroy, 1995). This chapter begins with a brief account of the roots of a cultural studies of law in order to set the stage for an examination of how a certain set of critical approaches to culture came to inform and transform our understanding of law. I then lay out a few of the main routes by which cultural analysis of law has traveled and the shrines and sights along those routes.

Given the diversity of approaches that can be characterized as cultural studies of law, there are many avenues that could be mapped onto this scholarly landscape. There is no town square or citadel to which these avenues lead, so the only option is to pick a few well-trod pathways and consider how they connect and diverge. I explore three routes along which a cultural analysis of law has been productively pursued: (1) narration, (2) identity, and (3) visuality. Narration is meant to embody a number of different approaches that apply a literary sensibility and critique to the language, interpretation, and rhetoric of law, legal arguments, and legal representations. It also seeks to capture the ways that law and representations of law (in novels, films, and other cultural artifacts) create certain kinds of enduring social narratives and tropes and perhaps teach normative lessons. Identity is a route paved by a robust scholarship that examines the role of law in developing, negotiating, policing, and enforcing certain kinds of individual and collective identities, including racial, ethnic, sexual, national and subnational identities that have been salient at different times. Lastly, I explore more briefly the smaller path of visuality, a recent effort to critically engage with the prominent portrayals of law and legal institutions in our pervasively visual culture as well as with the increasing use of visual arguments and iconography within law and legal practice.

\section{The Roots of a Cultural Studies of Law}

The roots of a cultural studies of law are found in various theoretical influences and interdisciplinary methods that together constitute cultural studies as a critical tradition in its own right. There are many different histories of cultural studies that could be told; my aim here is to mention the themes and concepts that most inform a cultural studies of law generally and, more specifically, the routes that I map below.

In my previous work with Mark Niles (2005), we subscribed to the relatively uncontroversial claim that modern cultural studies began in Britain in the 1960s at the Birmingham Centre for Contemporary Cultural Studies. These founding British cultural critics, such as Stuart Hall and Raymond Williams, focused on culture in at least two senses, as

both the meanings and values which arise amongst distinctive social groups and classes ... through which they "handle" and respond to the conditions of existence; and as the lived traditions and practices through which those "understandings" are expressed and in which they are embodied. (Hall 1994: 527) 
While the Birmingham School, like the earlier German Frankfurt School, was interested in the role of ideology in the reproduction of culture, it parted company with its predecessor by advancing the idea that cultural consumers exercise some agency as they make sense of and revise the meanings of their cultural practices and products. For example, British cultural scholars initiated the still-relevant method of reception studies, which investigates the ways in which audiences make sense of cultural texts. The Birmingham School's complex understanding of ideology came less from a strict Marxist structural approach and more from post-structuralism and Louis Althusser (1971), who meant by ideology "the whole conceptual system or set of stories and images through which people make sense of themselves, their lives and the material conditions of their existence" (Mezey and Niles, 2005: 108).

Part of what made the Birmingham School's ideas about culture so complex and influential was that they understood that people do not experience their beliefs or the narratives through which they make sense of the world (their ideology) as coerced by those with power. Here modern cultural studies has been indebted to the thinking of Antonio Gramsci and his theory of hegemony.

By hegemony Gramsci meant the ways in which the institutions of civil society (education, religion, culture) exercise power by inducing consent rather than through outright coercion. This idea is particularly important for illuminating the ways in which mass-mediated popular culture gets its ideological power: it doesn't force people to believe one thing or another, it merely makes certain ways of thinking and acting and being seem utterly normal and natural. (Mezey and Niles 2005: 108)

Culture deeply informs our common-sense assumptions, and according to Gramsci common sense is at once a product of the culture in which we live and a form of ideology. It is "the conception of the world which is uncritically absorbed by the various social and cultural environments in which the moral individuality of the average man is developed" (Gramsci 1971: 419).

Cultural studies relies not only on theories of culture and ideology, but on theories of power and epistemology. In these areas especially, it is indebted to a number of French scholars who in the 1970s and 1980s were laying out the foundations of postmodernism and new theories of power by rethinking the evolution of social organization, the history of Western intellectual life, and the discursive nature of language and interpretation. None of them has been as influential for a cultural studies of law as Michel Foucault, who argued that human subjects and the human sciences came into being at the same time and re-ordered our understanding of knowledge and the self as well as our experience of social organization and power (Foucault 1970). Particularly important to cultural studies has been Foucault's understanding of the forms that power takes, especially the more subtle and even enjoyable forms of disciplinary control evident in social institutions and cultural practices.

In Foucault's view, power now does not exercise itself through individual human action or large state institutions, but is rather diffused through particular disciplinary mechanisms Morenver. the discinlinarv mechanisms create characters or social roles to which 
we now must aspire (the normal child, the healthy body, the stable and obedient mind) and other deviant personas we must vigilantly avoid. (Binder and Weisberg 2000:473)

Just as important as his theory of power - for both cultural studies and law - has been Foucault's theory of resistance to power. Just as hegemonic power implies persuasion and internalization, regulatory and legal control implies some negotiation with the subjects of regulation. As Foucault puts it, "there is no relationship of power without the means of escape or possible flight. Every power relationship implies, at least in potential, a strategy of struggle" (Foucault 1982: 225).

At the core of cultural studies are the entwined conceptions of culture, ideology, and power that come primarily from anthropology, political theory, and philosophy, but all of these concepts are dependent in their application on language, reading, and interpretation. It is in this sense that a cultural studies of law has been most profoundly influenced by literary theory and has integrated many strands of literary criticism into its interdisciplinary method. In their masterful cultural history of literary criticism of law, Guyora Binder and Robert Weisberg canvass a number of different genres of literary theory that have become part of cultural studies itself as well as a cultural or literary analysis of law, including hermeneutics, narrative theory, rhetoric, and deconstructionism. In contrast, I want to emphasize the similarities rather than the differences between these literary approaches in the sense that they have jointly contributed to the most recent "interpretive turn" within law that occurred - not coincidently - alongside cultural studies and postmodern theory.

Regardless of genre, all literary theories share with cultural theory a common practice of reading texts (literary, cultural, legal) not just for the linguistic meanings implicit in the words, but reading them closely to understand what is said and what is left unsaid, to consider the ways texts act in and on the world, and to make sense of the larger signifying systems in which every text is embedded, whether that text is a novel, a judicial opinion, or a cultural practice. It was perhaps Roland Barthes, in his classic book Mythologies, who most explicitly applied literary theory to read cultural products - such as advertisements, sports, or movie stars - as texts, and "[to] read them semiotically for their connotative ideological messages, for the ways in which they tended to naturalize and universalize the values they expressed" (Mezey and Niles 2005: 107).

The intellectual and interdisciplinary roots of modern cultural studies were not foreign to all within the legal academy and were in fact shared by many critical legal studies and critical race theory scholars as well as the more humanistically oriented within law and society. A number of socio-legal scholars working mainly in sociology and cultural anthropology - such as Roger Cotterrell, David Engel, Patricia Ewick, Carol Greenhouse, Sally Merry, Austin Sarat, Susan Silbey, and Barbara Yngvesson helped lay the foundation for a cultural studies of law with their ground-breaking work on community, identity, and legal consciousness. ${ }^{1}$ Less empirical and equally influential, critical legal studies scholars and critical race theorists - such as Derrick Bell, Kimberle Crenshaw, Mark Kelman, David Kennedy, Charles Lawrence, Mari Matsuda, Gary Peller, Mark Tushnet, and Patricia Williams - applied ideas of 
identity, ideology, and power borrowed from cultural studies and its root traditions to create enduring scholarship that sits comfortably within a cultural studies of law.

In what follows, I link up the intellectual traditions within cultural studies to show how they have helped frame a cultural studies of law. Some of those linkages are quite evident: structural and poststructural accounts of ideology and hegemony, and Foucault's theories of knowledge and power, have been central to the literatures on membership, subordination, identity production, and the administrative state, and to the legal narratives of equality, neutrality, and legitimacy. Likewise, reading legal texts for their narrative strategies or reading literature for the way it elucidates, naturalizes, or condemns legal norms are both practices that depend on literary theory. Finally, the discussion of visuality should make clear that this avenue of cultural analysis of law partakes of most of the core theories of cultural studies.

\section{The Routes of a Cultural Studies of Law}

As noted above, this map is incomplete. There are many regions only gestured at and many important roads and landmarks that don't appear at all. I have chosen instead to tentatively lay out what many maps only mutely perform: the histories of influence, interaction, and conquest that resulted in the creation of an identifiable terrain about which someone could even propose boundaries, identify avenues of inquiry, and point out notable sights. In addition, among the many byways and paths, I have selected three routes that I think are especially scenic and along each I highlight a few important landmarks in the scholarship.

\section{Route 1: Narration}

In this section my intent is not to canvass the notable work within law and literature or make an argument for why law and literature form an important arena of a cultural studies of law (although I think they do). Nor am I using the term "narration" to mean simply storytelling, as it is sometimes narrowly used. My aim instead is to identify a few of the most interesting scholars of a cultural studies of law who use literary techniques (and sometimes literature itself) to think about how law operates culturally and discursively, by creating a seemingly independent language system, by narrating its own normative force, or by coming into relief and being illuminated by readings of literary or cultural narratives. I highlight two classic texts by Robert Cover and James Boyd White as well as a more recent work by Robin West.

Robert Cover's "Nomos and narrative" may be among the most revered and referenced works of early cultural analysis of law. For Cover, a nomos is a culture, and it is created and regulated through narrative. The opening lines explain its relationship to law:

We inhabit a nomos - a normative universe. We constantly create and maintain a world of right and wrong, of lawful and unlawful, of valid and void. The student of law may 
come to identify the normative world with the professional paraphernalia of social control. The rules and principles of justice, the formal institutions of the law, and the conventions of a social order are, indeed, important to that world; they are, however, but a small part of the normative universe that ought to claim our attention. No set of legal institutions or prescriptions exists apart from the narratives that locate it and give it meaning. (Cover 1983: 4)

Law and narrative cannot be understood apart from each other because law only exists within discourse (as do we all) and narratives create the rules of behavior by which we live in the world.

Cover's primary argument is that "the creation of legal meaning" - what he calls "jurisgenesis" - "takes place always through an essentially cultural medium" (Cover 1983: 11). And jurisgenesis is fundamentally dynamic, because a nomos requires not just a set of laws, and often institutional enforcement, but the narratives that give the law meaning and create communal normative commitments to that meaning by a community of people. This dynamism means that even though we might share the same laws, we don't always inhabit the same nomos because our understandings of what those laws mean is contested.

All Americans share a national text in the first or thirteenth or fourteenth amendment, but we do not share an authoritative narrative regarding its significance. And even were we to share some single authoritative account of the framing of the text - even if we had a national history declared by law to be authoritative - we could not share the same account relating each of us as an individual to that history. Some of us would claim Frederick Douglass as a father, some Abraham Lincoln, and some Jefferson Davis. (Cover 1983: 17-18)

This dynamism and multiplicity of meaning leads Cover to the destabilizing conclusion that "there is a radical dichotomy between the social organization of law as power and the organization of law as meaning" (Cover 1983: 18). But the problems and tensions created by the disagreements of legal meaning are also a check on institutional power and a source of transformative potential, as "exiled narratives" can be the basis for different normative visions to be resurrected in the future (Cover 1983: 19).

Cover "reads" the law of primogeniture in the Bible and the Constitutional interpretation in Bob Jones University v. United States (103 S. Ct. 2017 (1983)) as well as the competing narratives that accompanied each, to show that law and legal interpretations only come to have legal meaning and force once people make a commitment to them and are willing to live by those commitments. When they are, and when official and unofficial legal meanings diverge, then the formal law must use coercion and violence to assert its authority and those committed to a different normative meaning must be willing to suffer violence to resist. As Cover says, "Interpretation always takes place in the shadow of coercion" (Cover 1983: 40). One sees in Cover's thinking on narrative a strong debt to cultural theories of power, resistance, community, and interpretation. 
There is a strong affinity between the ways Cover uses cultural and literary analyses to explain law's normative power and the work of James Boyd White. To my mind, James Boyd Whites Justice as Translation is one of the best books of criticism of any flavor. It begins with the proposition that law is an entire language, not in the facile sense of being conducted primarily in words, but a language as a "repertoire of forms of action and of life" (White 1990: xi). In other words, White, like Cover, understands language in both a literary and a cultural sense, as a set of practices rather than a set of propositions, as a discourse through which its speakers know themselves and others, adopt habits of mind, and form communities and cultures that can be studied. White's purpose in the book is to study the culture of law through its language and to posit an ethics of speaking across very different languages and cultures that he likens to translation. Translation, for White, is not merely a way of traversing difference, but a "model of law and justice" in that both are fundamentally concerned with "establishing right relations" between people (White 1990: 230).

White begins by comparing the language and culture of law to that of economics and finds in the comparison that law assumes greater equality among speakers and a greater concern for individual and collective transformation. In Anglo-American law, the common law tradition creates a discourse committed to arguing about which past texts we are committed to, why they are or should be authoritative, and what they should mean for the future. This form of interpretive debate is how the law renews itself and changes and why White finds it to be a "radically literary" activity (White 1990: 91).

For what the law insists upon is that we are a discoursing community, committed to talking with each other about our differences of perception, feeling, and value, our differences of language and experience. The task of law is to provide a place and a set of institutions and methods where this conversational process can go on, as well as a second conversation by which the first is criticized and judged. Political power is divided up among separate actors under circumstances requiring that they talk to each other. This creates an occasion and necessity for deliberative and institutional politics, a method of collective thought, that is in principle wholly different from the expression of want or desire in the instant referendum of the market. (White 1990: 80)

This vision is, I believe, consciously idealized, to make a point about the possibilities of legal discourse in a society beset by profound difference and disagreement.

For White, legal discourse - like all discourse - is not "just" literary, but also political and ethical. In the bulk of the book he puts his claims to work, reading a series of important judicial opinions and asking of each: How does it create its authority? What kind of conversation does it authorize and model? How does it address the reader and what kind of relationship does that address envision? And what relation does the opinion create with those that it discusses?

In all of this the law can be seen as an enterprise of self-creation. There is no ground in nature, in the facts, or in uninterpreted texts, upon which the law and its authority can rest. Both law and authority are made, and largely made in the process of writing the 
opinions by which the decisions reached by the courts are given their meaning. In this sense the law can teach all of us how to live in a world in which each culture is its own ground, made out of itself, as a language or a human life is made out of its own beginnings. (White 1990: 217)

That law is a discourse, a form of narration, means for White that it is a worldmaking enterprise, a culture, that can be understood and assessed according to the ways in which it makes and remakes the world through language.

In contrast to the theoretical argument that law is a discursive and narrative system, I want to turn now to a more recent literary/cultural reading of law by Robin West that is somewhat more focused and exemplifies the insight and potential of a cultural study of law based on narrative techniques.

Many of Robin West's books and articles might be fruitfully chosen as an example of an elegant and richly textured literary approach to law. I discuss her essay Literature, Culture, and Law at Duke University because in it she offers a concise synthesis of law/literature and law/culture that is attentive to their divergence as well as a deftly interdisciplinary reading of the Duke rape allegations that highlights a cultural study of law inflected by both a literary sensibility and a commitment to the normative power of literature.

According to West, law and literature scholarship of the last 25 years falls into three main categories. The first, which she refers to as the literary wing of the movement, looks at great works of literature that take law as their subject matter in order to learn something about law that we cannot learn from it directly, namely "the meanings of law in the lives of its subjects, its agents, and its adjudicators and the meanings of law in the lives of those whom it willfully ignores, subjugates, marginalizes, or excludes" (West 2011: 100). The second category of law and literature is more historical and works from the conviction that literature can sometimes have the force of law and law can be read as literature. West argues that when elite lawyers were trained by reading legal, literary, religious and political classics it was easier to believe that literature could have the force of law because "[p]olitical authority and intellectual, moral, and cultural authority have not always been so separate" (West 2011: 102). Finally, there is the relationship between law and literature that is evident in the work of Cover and White - what West calls interpretive - in which law and literature both exist as texts, and are both objects of an interpretation that is not restrained "by the author's corporeal and historical being but rather by the interpretive community's norms and principles" (West 2011: 103). In this relation between law and literature, all that is left of literature is its method of reading.

West then goes on to show the parallels between the different ways of relating law and literature and the ways cultural studies of law relate law and culture. The first understands law and culture as distinct with law as the regulator of culture; culture, because it is not law; can at most disseminate or resist law's norms. The second possibility is a more expansive version of the interpretive strand of law and literature scholarship, in which law is both text and a set of cultural practices to be read in the same ways that we read culture. The last possibility is one that more fully embeds 
law in culture and culture in law so that the two cannot be adequately understood apart from each other. As socio-legal scholars have long argued, culture and law, in this sense, are always mutually constitutive. This version most closely resembles the cultural study of law I canvass and advance here, in that culture functions as and in law and law cannot be divorced from the culture in which it exists.

What West finds lacking in cultural studies of law is that there is no analogue to the literary strand of law and literature. "No one has advanced the claim that we should turn to culture, not only because culture disseminates legal ideas and is heavily informed by and informs law but also because the products of culture can deepen our understanding of law" (West 2011: 107). So West sets out to model a complex and entwined analysis of culture and literature that can illuminate law by "reading" the scandal that surrounded the discredited rape claim made by an African-American woman against the Duke lacrosse athletes who had hired her as a stripper. This reading is an example of "law as culture in all sorts of configurations" in which legal culture sometimes cooperated with and sometimes competed with a host of other cultures at play, such as "academic, athletic, sexual, and feminist subcultures, and their sometimes warring conceptions of the value of recreational sex" as well as the cultural differences between the city and the university, between blacks and whites, between the privileged and the poor (West 2011: 107).

It was in this context that culture both operated as law and enabled a legal injustice. West shows that culture is law in the sense that a rape claim by a black woman against white men could not have been brought a century ago when her consent would have been presumed or irrelevant. Nor could the charge have been brought thirty years ago because "[r]egardless of her color, the sex worker's consent to sex would have been presumed from the moment she entered the house" (West 2011: 108). The charge was not only possible in 2006 , because the culture allowed it, but believable precisely because of the continuing existence of a culture that accepts "sexual conquest as a natural entitlement of social or athletic success," that allows, in other words, a certain amount of rape and plenty of unwanted sex.

West then adds a powerful literary critique to her cultural reading. She shows how Tom Wolfe's novel, I Am Charlotte Simmons, in which an ambitious scholarship student is pressured into unwanted sex by a drunken lacrosse player, became an accepted and widely used shorthand in the media coverage for the rape culture among Duke athletes, such that the "fictional sexual assault of Charlotte Simmons made more credible the nonfictional charge of rape in Durham" (West 2011:111). The problem with the use of Wolfe's novel in the Duke scandal, according to West, was that it was inadequately attentive to the fictional narrative. In the novel, Charlotte Simmons is not raped. As diminished as she is by the experience, she does not say no, does not resist, and does not feel she has been assaulted.

The contribution of this novel is that it renders a full description of the experience of intrusive, unpleasurable, and undesired - but consensual - sex and the harm it can cause to one's character and emotional life. Wolfe's novel is and should be read as a 
critique of potent and harmful but nevertheless legal sex and of the culture that legitimates, honors, and encourages it. (West 2011: 112)

The contribution of West's literary and cultural reading is that she is alert to the many genuine cultural narratives that validated the false rape claim in Durham but also to the ease with which we use culture and literature superficially to augment our politics or perceptions of the law. By salvaging the content of the novel, West makes a powerful claim for the continuing importance of reading literature and culture for what it can teach us about law.

\section{Route 2: Identity}

Here I take a road well traveled in cultural studies of law. Identity politics and multiculturalism grew out of many of the same intellectual traditions as cultural studies itself, and law has always played a role in recognizing a right to the goods it distributes (citizenship, voting, antidiscrimination protection, property ownership, marriage recognition) based on membership or status - national, racial, sexual, etc. Thus it is no surprise that scholarship about identity has been a staple of cultural studies of law.

Again I begin with what I consider to be two classic texts of this genre, one by the ethnographer James Clifford engaging the law of tribal recognition from an anthropological perspective and one by Cheryl Harris about the legal recognition of cultural racial privilege written from the perspective of critical race theory. I then turn to a more recent work by Katherine Franke that complicates gay identity and rights by thinking about how they operate inside and outside the state, across national cultures and traditions, and as part of a politics of both nationalism and globalization.

Clifford's essay on the Mashpee Tribe's land litigation is a work of cultural analysis of law at its best and is widely respected across many disciplines. The litigation was an effort by the Mashpee Tribe to reclaim possession of lands that they alleged had been illegally sold without Congressional approval. But before they could litigate whether their former lands were protected by a statute meant to prevent native dispossession, they had to prove that they were a "tribe" within the meaning of the statute. The court's struggle to determine whether the aggregate of individuals before it was a tribe forms the central axis of Clifford's essay around which he explores the tensions between the legal and ethnographic accounts of tribal identity.

"The trial was essentially a conflict between two narratives of Indian history" (Binder and Weisberg 2000: 493). One narrative was a distinctly white and romantic narrative of coherent tribal identity maintained consistently over time and located in a recognizable leadership and territory and supported by written documentation. The defendants used this narrative to argue that the Mashpees were not a tribe but a set of refugees from other tribes who had effectively assimilated by becoming Christian and mixed-race, and abandoning their tribal governance, language, and 
traditions. The existence of teachers who taught Indian culture was used to argue that the Mashpees were inadequately Indian. The other narrative was the one presented by the Mashpees and their expert witnesses, in which tribal identity had been fluid in order to survive, and their religious conversion, loss of self-rule, and accommodation of white norms were not exactly voluntary. Moreover, they argued that their accommodations did not deprive them of their sense of tribal identity. They might be Baptists, but their religious services incorporated native beliefs and language and their churches were hubs of tribal culture.

Clifford uses the record of this litigation for a couple of different purposes. First, he seeks to rehabilitate identity generally and tribal identity specifically from the essentialism that the law seemed to impose, arguing that survival for cultural groups often means navigating, negotiating, and sometimes accommodating mainstream culture. Clifford explains how the white fantasy of traditional Indian identity, a fantasy shared by the law, cannot "account for complex historical processes of appropriation, compromise, subversion, masking, invention, and revival" (Clifford 1988: 338). He shows that the Mashpees seemed

sometimes separate and "Indian," sometimes assimilated and "American." Their history was a series of cultural and political transactions, not all-or-nothing conversions or resistances. Indians in Mashpee lived and acted between cultures in a series of ad hoc engagements. (Clifford 1988: 342)

Second, Clifford shows how law was integral to the ways in which the Mashpees "made and remade themselves" (Clifford 1988: 338) because Indians are both creatures and survivors of American law. In this sense, being forced by the court to assert their identity in a form recognizable to the law had an effect on the tribe and their collective identity. The lawsuit became "part of the story of the tribe's adaptation, not simply an alien imposition" (Binder and Weisberg 2000: 497).

Cheryl Harris, in her foundational article "Whiteness as property," provides a different take on the role of law in identity formation and negotiation. She lays out a legal and cultural history of how legal rights to property have been entangled with racial hierarchy and status since conquest and slavery, and have continued to support settled expectations of white privilege into the present. Starting from the premise that being white is a valuable asset that provides economic and political benefits, Harris shows how whites "have come to expect and rely on these benefits, and over time these expectations have been affirmed, legitimated, and protected by the law" (Harris 1993: 1713).

Harris notes that it was not race alone that created and maintained racial subordination and oppression, but the interaction between race and property such that property was a way to perpetuate and reproduce racial inequality. She locates the mutual reinforcement of race/property in both slavery and conquest. Slavery was the legal appropriation and commodification of black people's bodies and conquest was the legal appropriation of Indian land. In both cases, property consolidation in whites was premised on claims of racial hierarchy. The law explicitly justified both slavery 
and land dispossession in racialized terms. "Slavery produced a peculiar, mixed category of property and humanity - a hybrid possessing inherent instabilities that were reflected in its treatment and ratification by the law" (Harris 1993: 1718).

Harris's account is premised on an assumption shared by most cultural studies of legal identity - that race and racial difference are not biological facts but only come into being as a result of racialized ideology and social relations. In other words, race is socially constructed rather than a natural category of difference. One way that race is constructed is through the law.

The law's construction of whiteness defined and affirmed critical aspects of identity (who is white); of privilege (what benefits accrue to that status); and, of property (what legal entitlements arise from that status). Whiteness at various times signifies and is deployed as identity, status, and property, sometimes singularly, sometimes in tandem. (Harris 1993: 1725)

Harris carefully charts the conceptions of property that have supported a claim to whiteness as a property right, including a property right in intangible things, property rights based on custom and social relations, Bentham's idea of property on the basis of expectation, or Radin's personhood argument in which whiteness is fundamental to one's personhood. More functionally, property was understood as including an absolute right to exclude, and in this sense the one-drop rule operated to provide whites with the legal ability to exclude blacks - even those who were mostly white - from the privileges of whiteness. The one-drop rule simply institutionalized the social conditions that had paved the way for a property interest in whiteness.

Given the history of overt racial subordination, it is perhaps not surprising that a strong case can be made for a property right in whiteness. More surprising is Harris's analysis of how that property right continued to function even after de jure segregation was prohibited by Brown. To make this argument she contrasts Plessy v. Ferguson (163 U.S. 537 (1896)) with Brown v. Board of Education (347 U.S. 483 (1954)). In Plessy, the Supreme Court acknowledged a property right in the reputational interest of being white, and noted that a white man erroneously assigned to the "colored coach" would have an action against the train company. A black man like Plessy, on the other hand, had no right to the reputation of being a white man and therefore would have no property right to vindicate if he was seated in the "colored coach." In Brown, however, Harris argues that legal white privilege was invalidated at the same time that de facto white privilege was left in place:

In accepting substantial inequality as a neutral base line, a new form of whiteness as property was condoned. Material inequities between Blacks and whites - the product of systematic past and current, formal and informal, mechanisms of racial subordination - became the norm. Brown disregarded immediate associational preferences of whites, but sheltered and protected their expectations of continued race-based privilege. (Harris 1993: 1753)

This is the legacy with which we continue to live. 
While Clifford's account of the Mashpee trial is written from the perspective of ethnography and Harris's account of property rights in whiteness is a work of critical race theory, both pieces are important works within the capacious field of cultural studies of law because they highlight the ways in which law is often beholden to accepted stereotypes, custom, and settled expectation (culture) and also participates in constructing and enforcing certain identities at the same time that those legal identities are negotiated and contested by the very people who claim them. Both essays also depend on notions of racial ideology, hegemony and power in its many forms.

These same themes are evident in Katherine Franke's recent work on how a Western cultural embrace of gay rights is universalized and taken up by states as part of their own national efforts of global legitimacy and citizenship. In "Dating the state: The moral hazards of winning gay rights" (2012), Franke warns against the selective and strategic embrace of gay rights by states in order to burnish their liberal and modern credentials with Western states in spite of other "uncivilized" behavior, and sometimes at the expense of other minorities. Franke brings to bear rhetorical analysis; attention to local and global politics, power, and identity production; skepticism of a romantic multiculturalism; and a keen eye for the tensions between individual, collective and national identities.

Using the examples of Israel and Romania primarily, Franke shows how "[i]n hugely interesting ways, states have come to see that their political power, their legitimacy, indeed their standing as global citizens, are bound up with how they recognize and then treat 'their' gay citizens" (Franke 2012: 4). Formal and rhetorical acceptance of gay rights becomes a stand-in for human rights and therefore modernity. For example, as part of Romania's effort to accede to the EU, it had to show it respected human rights even though it had had a deplorable human rights record during Ceausescu's rule. Although the abuses were against gay people, women and the Roma, repeal of its law criminalizing homosexual conduct became its ticket for admission. Franke shows how a Dutch NGO worked with Romania to produce universal, liberated gay subjects who would be recognizable to the $\mathrm{EU}$ in much the same way that the Mashpees had to perform a recognizable Indian identity for the district court. According to Franke,

European rapporteurs went looking for something familiar - a society that had homosexuals just like their homosexuals, who were discriminated against in predictable ways by public and private actors, and who should and could seek legal protection for [sic] that discrimination from the state. For a state like Romania, serious candidacy for admission to the EU meant performing plausible modernity by having a recognizable minority of citizens who understood themselves to "have" a gay identity just as in the European metropole and who could then be recognized by the state as rights-bearing subjects. (Franke 2012: 28)

Franke goes on to point out, however, that "the almost singular focus on sexual rights as the marker of modernity has been accompanied by the neglect" of others; despite the praise Romania receives for the strides it has made on human rights, women and the Roma still fare very poorly (Franke 2012: 29). 
The critique Franke offers is complex and illuminating. She shows not only how gay citizens are produced and validated in order for countries to perform their own modernity on an international stage, but also how those subjectivities are scripted according to Western cultural norms. The Western human rights script "takes as given that all persons do, or should, understand themselves to have a sexual orientation and a gender identity, and that this sexually-oriented and gendered sense of self is fundamental not only to how they know themselves but fundamental to who they are" (Franke 2012: 32). Moreover, there can be danger for gay rights advocates in too readily accepting these global political negotiations as victories. Franke suggests that gay rights ought not to be readily universalized and that advocates should be more attentive to the cultural differences and hierarchies at play within each state and on the international stage. She cautions against trusting states as partners in gay liberation, particularly when those states are making bids for membership among the circle of "modern" Western states. Franke warns that in these situations gay rights advocates not only run the risk of being implicated in the marginalization of others and entangled in nationalist governance projects, but they are also likely to help reproduce universalized gay identity according to the Western human rights script rather than more culturally specific versions of subjectivity.

\section{Route 3: Visuality}

I end here because visuality is a newer and less developed route within the cultural studies of law, and because in many ways it is an area that beckons toward the future. Unlike the preceding sections, this one does not review noteworthy examples of the scholarship, but instead offers a brief account of the kinds of work this area inspires. Studies of legal imagery in its many forms - television and film about the law, photographic and video evidence, multimedia graphics, illustrations, computer animations, videotaped confessions and victim impact statements, police body cameras, political documentaries - will almost certainly grow as legal practice and new trial technologies continue to become more visual and tactile and less textual. As Austin Sarat has said, "Today we may be witnessing a movement from law on the books to law in action to law in the image" (Sarat 2011: 3). But it is not simply changes in legal practice that have fueled a scholarly interest in visuality. In some of its manifestations, studies of legal imagery are an offshoot of the narrative investigations discussed above, in which images are read for their insights, critiques, imaginings, and longings of law. In whatever form it takes, "the visual has occasioned a paradigm shift in the way legal meaning is constructed" (Mezey 2013: 6).

Methodologically, this strand of a cultural studies of law makes use of many tools of cultural studies, and adds to them a rich literature in film and contemporary media studies. These methods have been applied to three main sorts of scholarly inquiries, which Jessica Silbey has termed "law-in-film," "film-as-law," and "film as evidence" (Silbey 2012/13: 177-178). The first of these focuses on representations of law in visual popular culture in much the way that West's literary strand of law and 
literature focused on law in literature, in order to deepen our understanding of law's role in the lives of its subjects and agents. The second approach, film-as-law, also applies to all visual popular culture, and it "asks how films about law constitute a legal culture beyond the film. This approach pays special attention to film's unique qualities as a medium and asks how its particular ways of world-making shape our expectations of law and justice in our world" (Silbey 2012/13: 177). Film-as-law aligns with law-as-culture in the sense that it understands law and visual culture as two signifying systems that are nonetheless dependent on each other for their fullest meanings. The third approach that Silbey identifies is film as evidence, which could be aptly termed "film-in-law," in that it studies the use of visual tools within the law, as evidence, testimonial aid, counter-narrative, or affective prompt. In this scholarship, "the history of film as entertainment and as an art form combines with the epistemological complexities inherent in this representational medium to explore the benefits and pitfalls of film's role in shaping formal legal procedures" (Silbey 2012/13: 178).

There is, I think, another category that addresses legal visuality in ways not captured by thinking only cinematically, and this is work that explores law's engagement with art, advertising, architecture, performance, and iconography. Like other forms of visuality, these images also frame, influence, and disrupt legal meanings and offer new ways of knowing what we know. As one especially rich example, Alison Young's work on street art and graffiti works across law, culture, and criminality in ways that reconfigure their boundaries. She suggests that attention to street art, as image, communication, and cultural practice, can revise our understanding of cities and public space, private property, trespass and criminality, art, authorship and political speech. Young conveys how street art's high risks and no profit, combined with the enchantment of the unauthorized and unexpected, give it the quality of a gift: "the artist seeks to make a gift of the artwork to the spectator, the neighbourhood and the city itself" (Young 2014: 27). The method is interdisciplinary in the best sense, combining ethnography, visual studies, criminality, and cultural theory, all in the service of showing how this one "cultural practice can be art and crime and an aspect of urban space and a form of communication and a political gesture and constitutive of a new movement in art" (Young 2014: 8). In Young's generous rendering, the footpath of visuality is indeed leading us into the future, but it will not lead into a public pastoral wood; rather, it delivers us into a privatized urban jungle that is crisscrossed by law and regulation. "Meanwhile, the cityscape is configured as a conglomeration of crime scenes, which result from acts of trespass across boundaries that are supposedly impregnable" (Young 2014: 138).

\section{Note}

1 Here the editors of this volume deserve particular recognition. Patricia Ewick, along with co-author Susan Silbey, has produced work that sits comfortably within law and society that nonetheless speaks with and contributes to scholarship outside the social sciences 
and engages many of the ideas of ideology, power, and resistance at the core of cultural studies. Austin Sarat, for his part, led the way for a group of like-minded scholars both within and outside law and society to develop a community and a literature focused on law, culture, and humanities. This literature is jurisprudential and yet grounded in critical and cultural theory. In so many ways Sarat has founded the modern cultural study of law through mentoring, institution building, innumerable anthologies, and sheer force of personality.

\section{References}

Althusser, L. (1971). Lenin and Philosophy and Other Essays. New York: Monthly Review Press.

Binder, G. and Weisberg, R. (2000). Literary Criticisms of Law. Princeton, NJ: Princeton University Press.

Clifford, J. (1988). The Predicament of Culture: Twentieth-Century Ethnography, Literature, and Art. Cambridge, MA: Harvard University Press.

Clifford, J. (1997). Routes: Travel and Translation in the Late Twentieth Century. Cambridge, MA: Harvard University Press.

Coombe, R. J. (1998). Contingent articulations: A critical cultural studies of law. In A. Sarat and T. R. Kearns (eds.), Law in the Domains of Culture. Ann Arbor, MI: University of Michigan Press.

Cover, R. M. (1983). Nomos and narrative. Harvard Law Review 97: 4-68.

Foucault, M. (1970). The Order of Things: An Archeology of the Human Sciences. New York: Pantheon.

Foucault, M. (1982). Afterword: The subject and power. In H. L. Dreyfus and P. Rabinow (eds.), Michel Foucault: Beyond Structuralism and Hermeneutics. Chicago: University of Chicago Press.

Franke, K. (2012). Dating the state: The moral hazards of winning gay rights. Columbia Human Rights Law Review 44: 1-46.

Geertz, C. (1983). Local Knowledge: Further Essays in Interpretive Anthropology. New York: Basic Books.

Gilroy, P. (1995). The Black Atlantic: Modernity and Double-Consciousness. Cambridge, MA: Harvard University Press.

Gramsci, A. (1971). Selections from the Prison Notebooks. New York: International Publishers.

Hall, S. (1994). Cultural studies: Two paradigms. In N. B. Dirks, G. Eley, and S. B. Ortner (eds.), Culture/Power/History: A Reader in Contemporary Social Theory. Princeton, NJ: Princeton University Press, pp. 520-538.

Harris, C. I. (1993). Whiteness as property. Harvard Law Review 106: 1709-1791.

Kahn, P. W. (1999). The Cultural Study of Law: Reconstructing Legal Scholarship. Chicago: University of Chicago Press.

Mezey, N. (2001). Law as culture. Yale Journal of Law \& Humanities 13: 35-67.

Mezey, N. (2013). The image cannot speak for itself: Film, summary judgment and visual literacy. Valparaiso University Law Review 48: 1-39.

Mezey, N. and Niles, M. C. (2005). Screening the Law: Ideology and Law in American Popular Culture. Columbia Journal of Law er the Arts 28: 91-185. 
Sarat, A. (2011). What popular culture does for, and to, law. In A. Sarat (ed.), Imagining Legality: Where Law Meets Popular Culture. Tuscaloosa, AL: University of Alabama Press, pp. 1-16.

Sarat, A. and Kearns, T. R. (eds.) (1998). Law in the Domains of Culture. Ann Arbor, MI: University of Michigan Press.

Silbey, J. (2012/2013). Images in/of law. New York Law School Law Review 57: 171-183.

West, R. (2011). Literature, culture, and law at Duke University. In A. Sarat, C. O. Frank, and M. Anderson (eds.), Teaching Law and Literature. New York: Modern Language Association, pp. 98-113.

White, J. B. (1990). Justice as Translation: An Essay in Cultural and Legal Criticism. Chicago: University of Chicago Press.

Young, A. (2014). Street Art, Public City: Law, Crime and the Urban Imagination. New York: Routledge. 